\title{
Dietary glycemic load, glycemic index, and refined grains intake are associated with reduced $\beta$-cell function in prediabetic Japanese migrants
}

\author{
Associação entre carga glicêmica da dieta, índice glicêmico \\ e consumo de cereais refinados e função reduzida das \\ células- $\beta$ em migrantes japoneses com pré-diabetes
}

Daniela Saes Sartorelli', Laércio Joel Franco', Renata Damião², Suely Gimeno 3 , Marly Augusto Cardoso ${ }^{4}$, Sandra Roberta Gouvea Ferreira $^{3.4}$ for the Japanese-Brazilian Diabetes Study Group

\begin{abstract}
Objective: To investigate the association between carbohydrate intakes and $\beta$-cell function (HOMA- $\beta$ ) in Japanese-Brazilians with impaired glucose tolerance (IGT). Methods: Dietary intakes were assessed by a validated food frequency questionnaire in a cross-sectional survey carried out in 2000. The associations between diet and HOMA- $\beta$ were verified in 270 newly diagnosed IGT in multiple linear regression models. Results: The mean (SD) age was 58 (11) years and the mean HOMA- $\beta$ was 65 (47). The glycemic load was inversely associated with HOMA- $\beta$, $\beta 1-0.140(95 \% \mathrm{Cl}=-1.044 ;-0.078), p=0.023$. The inverse association was also observed for refined grains intakes: $-0.186(95 \% \mathrm{Cl}=-0.4862 ;-0.058), \mathrm{p}=0.012$. After adjustments for body mass index, the glycemic index was inversely associated with HOMA- $\beta$ : $-0.1246(95 \% \mathrm{Cl}=-2.2482$, $-0.0257), p<0.001$. Conclusions: These data suggested that dietary glycemic load, glycemic index, and refined grains intakes are associated with reduced $\beta$-cell function, and the quality of dietary carbohydrates may be relevant for maintaining $\beta$-cell function among individuals with IGT. Arq Bras Endocrinol Metab. 2009;53(4):429-34.
\end{abstract}

Keywords

Dietary carbohydrates; glycemic index; prediabetic state; emigrants and immigrants

\section{RESUMO}

Objetivo: Investigar a associação entre o consumo de carboidratos e função das células- $\beta$ (HOMA- $\beta$ ) em nipo-brasileiros portadores de tolerância à glicose diminuída (TGD). Métodos: O consumo alimentar habitual foi avaliado por meio do questionário quantitativo de frequência alimentar previamente validado em estudo transversal conduzido em 2000. A associação entre dieta e HOMA- $\beta$ foi verificada em 270 indivíduos portadores deTGD em modelos de regressão logística ajustados. Resultados: A média (DP) de idade foi 58 (11) anos e do HOMA- $\beta$ foi 65 (47). A carga glicêmica foi inversamente associada ao HOMA- $\beta, \beta 1-0.140(95 \% \mathrm{Cl}=-1.044 ;-0.078)$, $p=0,023$. Associação inversa com o consumo de cereais refinados também foi observada: $-0.186(95 \% \mathrm{Cl}=-0.4862 ;-0.058), p=0,012$. Após ajuste pelo índice de massa corpórea, foi verificada a associação inversa entre índice glicêmico e HOMA- $\beta$ : $-0.1246(95 \% \mathrm{Cl}=-2.2482,-0.0257)$, $\mathrm{p}<0,001$. Conclusões: Os dados indicam que a carga glicêmica da dieta, o índice glicêmico e o consumo de cereais refinados estão associados a uma função reduzida das células- $\beta$ e que a qualidade dos carboidratos da dieta habitual pode ser relevante na manutenção da função de células- $\beta$ entre indivíduos portadores de TGD. Arq Bras Endocrinol Metab. 2009;53(4):429-34.
Departamento de Medicina Social, Faculdade de Medicina de Ribeirão Preto (FMRP), Universidade de São Paulo (USP), Ribeirão Preto, SP, Brazil

${ }^{2}$ Departamento de Nutrição, Universidade Federal do Triângulo Mineiro (UFTM), Uberaba, MG, Brazil ${ }^{3}$ Departamento de Medicina Preventiva, Universidade Federal de São Paulo (Unifesp), São Paulo, SP, Brazil ${ }^{4}$ Departamento de Nutrição, Faculdade de Saúde Pública, USP, São Paulo, SP, Brazil

Correspondence to: Daniela Saes Sartorelli Av. Bandeirantes, 3.900 14049-900 - Ribeirão Preto, SP, Brasil daniss@fmrp.usp.br

Received in Oct/17/2008 Accepted in Mar/3/2009 


\section{INTRODUCTION}

$\mathrm{T}$ he genesis of type 2 diabetes mellitus (T2DM) is multifactorial, and environmental factors implicated are still a matter of discussion. Such knowledge is of considerable interest, taking into account its worldwide epidemic (1). Dietary habits are an important target of investigation. Migrant populations represent a unique opportunity to investigate possible role of contrasting dietary habits imposed by moving from one environment to other, as an underlying mechanism of glucose intolerance. It is controversial whether the progressive deterioration of $\beta$-cells in a setting of chronic insulin resistance $(2,3)$ could be exacerbated by the quantity and the type of carbohydrate intake $(4,5)$. Japanese migrants in Brazil have one of the highest prevalence of diabetes reported in literature (6). Our group previously showed that dietary fat may contribute for the occurrence of metabolic syndrome among Japanese-Brazilians (7). However, it was not known if the carbohydrate consumption could be associated with $\beta$-cell function.

The gold standard to estimate $\beta$-cell function, the euglycemic hyperinsulinemic clamp technique, is time consuming, invasive and unsuitable for the use in large scale. Alternatively, the homeostasis model assessment (HOMA- $\beta$ ) has been used $(8,9)$, providing surrogate measures of $\beta$-cell function and with good correlations (from 0.7 to 0.88 ) with the clamp (10).

Insulin hypersecretion is typical of early stages of the disturbance of glucose homeostasis; in long-term, this may progress to $\beta$-cell deficiency and T2DM (11). Impaired $\beta$-cell function and insulin resistance can be detected in individuals with impaired glucose tolerance (IGT) and impaired fasting glucose (IFG). Although both disturbances are intermediate states between normal glucose tolerance and T2DM, the metabolic abnormalities and pattern of impaired insulin secretion are distinct, suggesting that the pathways to prevent their progression to T2DM might be different (12). The role of usual intake of carbohydrates on $\beta$-cell dysfunction in prediabetic individuals are sparse and inconclusive $(4,13,14)$. The aim of this study was to investigate the association between the quantity and the quality of carbohydrate intakes on $\beta$-cell function (HOMA- $\beta$ ) in Japanese-Brazilians with IGT.

\section{METHODS}

In 2000, a cross-sectional study was carried out in the entire Japanese-Brazilian population over 30 years of age living in Bauru, São Paulo, Brazil $(\mathrm{n}=1,751)$. Data collection from 1,283 first (Japan-born) and secondgeneration (Brazil-born) subjects were available (participation rate of $73.3 \%$ ) (6). For the present analysis, 270 newly diagnosed IGT individuals with complete data were considered. The Ethics Committee of the Universidade Federal de São Paulo (Unifesp) approved the study protocol, and written informed consent was obtained from all participants. The investigation was carried out in accordance with the principles of the Declaration of Helsinki.

Demographic variables, smoking status, drinking habits and physical activity were assessed using a structured questionnaire. Height, weight, and waist circumference were measured using standardized approaches (15).

Food consumption was assessed using a food frequency questionnaire (FFQ) developed and validated among Japanese-Brazilians against results obtained from 3-day weighed dietary records (16). Subjects were asked about frequency of food intake (122 food items) and portion sizes during the previous year. Four portion sizes were given for selection: small, medium, large and extra large. Complete rechecking of the coding, as well as double keying, was performed for every questionnaire. The nutrient composition of diets was calculated using the DietSys software version 4.01. The nutrient database used was based primarily on United States Department of Agriculture publications, including the fructose content of each food, supplemented by the most recent edition of standard food composition tables of Brazil and Japan. Dietary exposures included intakes of total carbohydrate, fiber, refined-grain foods (rice, white bread, pasta), glycemic index (GI) and glycemic load (GL). GI and GL were estimated based on the International Table of Glycemic Index (17). Nutrient composition of diets was calculated using the DietSys software version 4.01 .

Blood samples were obtained after an overnight fast and a standard 75-g oral glucose tolerance test was performed. Plasma glucose was determined by the glucoseoxidase method and insulin by monoclonal antibodybased immunofluorimetric assay (AutoDelfia, PerkinElmer Life Science Inc, Norton, OH, USA). IGT was defined according to World Health Organization (WHO) criteria (18). HOMA was used to estimate $\beta$-cell function: [HOMA- $\beta=20 \mathrm{x}$ fasting insulin $(\mathrm{mU} / \mathrm{mL}) /$ fasting glucose $(\mathrm{mmol} / \mathrm{L})-3.5$ ], and insulin resistance [HOMA$\mathrm{IR}=$ fasting insulin $(\mathrm{mU} / \mathrm{mL}) \times$ fasting glucose $(\mathrm{mmol} /$ L)/22.5], according to Matthews and cols. (10). 
For descriptive analysis, the HOMA was cathegorized into tertiles based on values from all subjects. The HOMA- $\beta$ and dietary variables were log-transformed. Nutrients intake were energy-adjusted by the residual method. ANOVA and Tuckey's test, and $\chi^{2}$ were applied to analyze differences of continuous and categorical variables according to HOMA- $\beta$ tertiles.

The relations of the dietary carbohydrates and HOMA- $\beta$ was verified using multiple linear regression models adjusted for gender (Male/Female), age (Years), waist circumference $(\mathrm{cm})$, practice of physical activity at work or leisure time (Yes/No), smoking (Never, Past, Current), education $(\mathrm{No},<8$ years, $\geq 9$ years), intakes of alcohol (No, 0-54 g/day, > 54 g/ day) and total calories (kcal/day). On further analysis, the body mass index (BMI) was included on the final models. Given the high correlation between the dietary variables analysed, separated models were applied. Statistical analyses were performed using the Statistical Package for Social Sciences version 14.0. The level of significance was set at 0.05 .

\section{RESULTS}

The mean age (SD) of the 270 participants in the study was 58 (11) years; $56 \%$ were women and $80 \%$ from second generation. Their mean BMI was $25(4) \mathrm{kg} / \mathrm{m}^{2}$; mean values of waist circumference were $89(9) \mathrm{cm}$ and $80(9) \mathrm{cm}$ for men and for women, respectively. Fiftynine percent of the participants had $<8$ years of school attendance; $43 \%$ reported usual alcohol consumption; $73 \%$ never smoked; and $76 \%$ was classified as sedentary individuals. Their median (P25, P75) HOMA- $\beta$ was 54 $(35,82)$, and HOMA-IR $1.9(1.3,2.8)$.

The table 1 describes the main characteristics and nutrient intake across HOMA- $\beta$ tertiles. Higher mean value of fasting plasma glucose of individuals on the second tertile of HOMA- $\beta$ was observed when compared with the lowest tertile. Higher mean values of waist circumference, BMI, and HOMA-IR were verified among Japanese-Brazilians on the third tertile of HOMA- $\beta$, when compared with individuals on the second and first tertile. Conversely, lower mean age and frequencies of less than one year of attendance at school were verified among individuals on the highest tertile of HOMA- $\beta$. Individuals on the lowest tertile of HOMA- $\beta$ related usual diets with higher contents of GI.

The mean (SD) intake of energy was 1,995 (592) $\mathrm{kcal} /$ day. The median intakes of total carbohydrates,
GI, GL and refined grains are shown on table 2. In adjusted multiple linear regression models, the GL and refined grains intake were inverse and independently associated with HOMA- $\beta$ in those individuals with IGT. On further analysis, after adjustments for BMI, the GI was inverselly associated with HOMA- $\beta$, and the relation between GL, refined grains and carbohydrates did not change substancially. No associations were observed with total carbohydrate, fiber and GI intake, and between carbohydrate consumption and HOMA-IR on the tested models.

\section{DISCUSSION}

The investigation of lifestyle factors related to $\beta$-cell function among individuals with IGT is relevant for diabetes mellitus prevention strategies. Our results showed that high intake of refined grains and a diet with high GL and high GI were independently associated with reduced $\beta$-cell function among Japanese-Brazilians with IGT.

The present study compared the effect of different types of dietary carbohydrates on $\beta$-cell function among individuals with IGT. One important fact of this approach is that the results obtained are of great interest on Public Health policies to develop strategies on primary prevention of T2DM among high risk individuals. The weaknesses of the study include the small sample size, and the limitations inherent to the crosssectional surveys, since exposures (diet) and outcome (HOMA- $\beta$ ) were assessed at a single point in time and it is not possible to determine whether the exposure preceded or resulted from the outcome. The present analyzes included only newly diagnosed impaired glucose tolerant individuals to minimize this bias. Other limitation of the present study are related to the assessments of physical activity, since the questionnaire was not validated among the Japanese-Brazilians, which could, in part, explain the absence of association between physical activity and the outcomes explored.

Given the IGT and IFG are distinct metabolic abnormalities with different patterns of impaired insulin secretion, they might not present the same pathways into the progression to T2DM (12). HOMA estimates the basal state of insulin and glucose in terms of resistance and $\beta$-cell function, and the evaluation of both values combined, HOMA-IR and HOMA- $\beta$, are recommended (19). On the present study, only individuals with IGT, characterized by severe muscle insulin resistance, were considered (12), and the results reflect the $\beta$-cell function among in- 
Table 1. Characteristics of the study population and nutrient intake according to HOMA- $\beta \%$ tertiles

\begin{tabular}{|c|c|c|c|c|}
\hline & \multicolumn{3}{|c|}{ НОМА- $\beta \%$ tertiles } & \multirow[b]{2}{*}{$\mathbf{p}$} \\
\hline & $\begin{array}{c}<40.36 \\
n=90\end{array}$ & $\begin{array}{c}40.37-69.3 \\
n=90\end{array}$ & $\begin{array}{c}>70 \\
\mathrm{n}=90\end{array}$ & \\
\hline \multicolumn{5}{|l|}{ Mean (SD) } \\
\hline Age (years)* & $61(10)$ & $57(11)$ & $56(11)$ & 0.02 \\
\hline \multicolumn{5}{|l|}{ Waist circumference (cm) } \\
\hline $\operatorname{Men}^{*} \dagger$ & $83(10)$ & $89(8)$ & $94(8)$ & 0.00 \\
\hline Women* & $78(11)$ & $80(9)$ & $84(8)$ & 0.01 \\
\hline Body mass index $\left(\mathrm{kg} / \mathrm{m}^{2}\right)^{\star} \dagger$ & $23(4)$ & $25(3)$ & $27(4)$ & 0.00 \\
\hline \multicolumn{5}{|l|}{ Frequency (\%) } \\
\hline Male/Female & $31.6 / 34.6$ & $33.3 / 33.3$ & $35.0 / 32.0$ & 0.34 \\
\hline $1^{\text {st }} / 2^{\text {nd }}$ Generation & $40.7 / 31.6$ & $31.5 / 34.0$ & $27.8 / 34.4$ & 0.43 \\
\hline Education: & & & & 0.01 \\
\hline$<1$ year** $^{\star *}$ & 53.3 & 30.0 & 16.7 & \\
\hline $1-8$ years & 36.1 & 30.1 & 33.1 & \\
\hline$\geq 8$ years & 24.3 & 37.4 & 38.3 & \\
\hline Smoking ${ }^{\star *}$ & & & & 0.01 \\
\hline Current & 36.8 & 31.6 & 31.6 & \\
\hline Past & 16.7 & 46.3 & 37.0 & \\
\hline Never & 37.6 & 29.9 & 32.5 & \\
\hline Practice of physical activity & 38.5 & 33.8 & 37.7 & 0.48 \\
\hline Alcohol consumption & & & & 0.31 \\
\hline Never & 31.6 & 30.3 & 38.2 & \\
\hline 0 - 54 g/daily & 39.4 & 36.4 & 24.2 & \\
\hline$>54$ g/daily & 30.8 & 38.5 & 30.8 & \\
\hline \multicolumn{5}{|l|}{ Median (P25, P75) } \\
\hline Fasting glucose $(\mathrm{mg} / \mathrm{dL})^{*}$ & $115(110,129)$ & $113(107,117)$ & $110(103,116)$ & 0.01 \\
\hline $2 \mathrm{~h}$ glucose (mg/dL) & $159(149,171)$ & $159(150,171)$ & $155(147,167)$ & 0.28 \\
\hline $\mathrm{HOMA}-\mathrm{IR}^{*} \dagger$ & $1.1(0.7,1.5)$ & $2.0(1.7,2.3)$ & $3.5(2.8,4.3)$ & 0.00 \\
\hline Energy (kcal) & $1,922(1,610,2,412)$ & $1,959(1,596,2,368)$ & $1,918(1,520,2,460)$ & 0.09 \\
\hline Carbohydrate (E\%) & $54(50,58)$ & $53(49,59)$ & $52(48,57)$ & 0.30 \\
\hline Protein (E\%) & $14(12,16)$ & $13(11,15)$ & $13(11,15)$ & 0.62 \\
\hline Fat (E\%) & $32(28,36)$ & $32(29,36)$ & $32(29,36)$ & 0.15 \\
\hline Fibre (g) & $17(12,22)$ & $16(13,22)$ & $16(13,22)$ & 0.76 \\
\hline Refined grains $(\mathrm{g})^{\star}$ & $490(370,525)$ & $461(340,528)$ & $438(269,525)$ & 0.05 \\
\hline Fruits (g) & $274(139,464)$ & $268(138,446)$ & $210(96,428)$ & 0.54 \\
\hline Vegetables (g) & $194(132,253)$ & $185(128,233)$ & $182(130,258)$ & 0.64 \\
\hline Dietary glycemic index* & $88(82,91)$ & $85(80,90)$ & $85(91,89)$ & 0.02 \\
\hline Dietary glycemic load & $222(193,275)$ & $217(178,271)$ & $213(169,271)$ & 0.46 \\
\hline
\end{tabular}

${ }^{\star} \mathrm{p}<0.05$, ANOVA, differences between the first and second tertile (Tuckey's test); $\uparrow p<0.05$, ANOVA, differences between the second and third tertile (Tuckey's test); ${ }^{* \star} p<0.05, \chi^{2}$.

dividuals with high degrees of insulin resistance. The euglycemic clamp method is considered the gold standard to evaluate insulin resistance and $\beta$-cell function, but might not be suitable for epidemiological studies. Some of the limitatons of HOMA are that under constant insulin resistance, as IGT individuals, the degree of change in insulin concentration, according to the change in the fasting glucose, is not a uniform inverse relationship, which is an important limitation of the use of HOMA (20). Moreover, since the HOMA is a measure of basal insulin sensitivity and $\beta$-cell function in contrast to clamps, it does not provide a profile on the stimulate state (19). 
Table 2. Median (percentile 25, percentile 75) daily intakes of nutrients, glycemic index, and glycemic load, and regression coefficient $\beta 1$ (95\%Cl) for log-transformed HOMA- $\beta$ in Japanese-Brazilians with impaired glucose tolerance $(n=270)$, Bauru, Brazil, 2000

\begin{tabular}{|c|c|c|c|c|}
\hline & $\begin{array}{l}\text { Median intake } \\
\text { (P25, P75) }\end{array}$ & $\beta 1$ (95\%Cl) & $\mathbf{R}^{*}$ * & p \\
\hline Total carbohydrate intake (g/day) & $252(208,317)$ & & & \\
\hline Model $1 \dagger$ & & $-0.1135(-1.1977,0.0257)$ & 0.19 & 0.06 \\
\hline Model $2^{\star \star}$ & & $-0.1089(-1.2104,0.0742)$ & 0.13 & 0.08 \\
\hline Total dietary fiber intake (g/day) & $16(12,22)$ & & & \\
\hline Model 1 & & $0.0627(-0.1383,0.4349)$ & 0.18 & 0.37 \\
\hline Model 2 & & $0.0886(-0.1337,0.4572)$ & 0.13 & 0.08 \\
\hline Refined grains (g/day) & $469(311,532)$ & & & \\
\hline Model 1 & & $-0.186(-0.4625,-0.05833)$ & 0.20 & 0.01 \\
\hline Model 2 & & $-0.2113(-0.5039,-0.0894)$ & 0.15 & 0.00 \\
\hline Dietary glycemic index & $86(82,91)$ & & & \\
\hline Model 1 & & $-0.1048(-2.039,0.1266)$ & 0.18 & 0.08 \\
\hline Model 2 & & $-0.1246(-2.2482,-0.0257)$ & 0.14 & 0.00 \\
\hline Dietary glycemic load & $217(182,272)$ & & & \\
\hline Model 1 & & $-0.140(-1.04414,-0.07876)$ & 0.19 & 0.03 \\
\hline Model 2 & & $-0.2697(-0.9841,-0.1015)$ & 0.14 & 0.02 \\
\hline
\end{tabular}

* Multiple correlate coefficient of the explanatory variables; $†$ linear regression models adjusted for gender, age, waist circumference, physical activity, smoking, education, intakes of alcohol and total calories; ${ }^{\star \star}$ model 2: model 1, except by the replacement of waist circumferences for body mass index.

Previous studies suggest a role of type of dietary carbohydrate on insulin sensitivity and metabolic syndrome. Data from the Framingham Offspring Cohort Study revealed that usual diets with high GI and GL, and refined grains intake were positively associated with HOMA-IR and metabolic syndrome (21). In the Insulin Resistance Atherosclerosis Study, higher intakes of whole grains were related with increases in insulin sensitivity (14). But, the role of dietary carbohydrates on insulin secretion among high risk individuals remains controversial $(4,13,22)$.

Evidences from randomized clinical trials suggested that the type of carbohydrates consumed also seemed to be relevant on early insulin secretion in obese persons with metabolic syndrome (4). In these investigation, rye bread and pasta intakes improved early insulin secretion, when compared with obese individuals who consumed a diet rich in wheat bread, potatoes and oat after a 12-week follow-up. In another randomized clinical trial, a high-carbohydrate, low GI diets, improved insulin secretion when compared with a high-carbohydrate, high GI diets, in individuals with IGT after four months of follow-up (22). On a randomized crossover trial conducted among post-menopausal women, highfiber rye bread intake were associated with an increased acute insulin response, suggesting a protective role of high fibre content of diets on $\beta$-cell function (5).
Our findings are consistent with these previous studies and showed the relevance of the type of carbohydrates in maintaining $\beta$-cell function, independent of age, waist circumference, physical activity, alcohol consumption and total energy intake, known relevant risk factors for insulin resistance (23). One possible pathway is based on the concept that high intakes of fast absorbed carbohydrates might increase the postprandial rise in insulin quickening the exhaustion of pancreatic cells (24). Moreover, on the present study, the GI was inversely associated with HOMA- $\beta$ only after adjustments for BMI, which is in accordance with previous studies that showed a stronger deleterious metabolic effect of GI among overweight individuals and prone to insulin resistance $(25,26)$.

In conclusion, our finding suggested that high intakes of refined grains intake and usual diets with high GL diet are associated with reduced $\beta$-cell function in pre-diabetic Japanese-Brazilians. Longitudinal investigations are needed to test whether changes in the type of carbohydrates consumed could be beneficial in the natural history of glucose intolerance.

*Appendix: members of Japanese-Brazilian Diabetes Study Group: Alcides Hirai, Amélia T. Hirai, Helena Harima, Magid Iunes (in memoriam), Mário Kikuchi, Katsumi Osiro, Sandra R. G. Ferreira (Departamento de Nutrição, Universidade de São Paulo (USP), São Paulo, SP, Brazil), Suely G. A. Gimeno (Departamento de Medicina Preventiva, Unifesp, São Paulo, SP, Brazil); Katsunori Wakisaka (Japanese-Brazilians Study Center, Brazil); Daniela Saes 
Sartorelli, Laércio J. Franco (Departamento de Medicina Social, Faculdade de Medicina de Ribeirão Preto (FMRP), USP, Ribeirão Preto, SP, Brazil); Marly Augusto Cardoso (Departamento de Nutrição, Escola de Saúde Pública, USP, São Paulo, SP, Brazil); Nilce Tomita (Faculdade de Odontologia de Bauru, USP, Bauru, SP, Brazil); Newton de Barros Jr. (Departamento de Cirurgia, Unifesp, São Paulo, SP, Brazil); Regina C. S. Moisés, Luiza Matsumura (Departamento de Medicina, Unifesp, São Paulo, SP, Brazil); Rita Chaim (Departamento de Nutrição, Universidade do Sagrado Coração, Bauru, SP, Brazil); Vania D'Almeida (Departamento de Pediatria, Unifesp, São Paulo, SP, Brazil); Renata Damião (Departamento de Medicina Preventiva, Unifesp, São Paulo, SP, Brazil).

Acknowledgements: Supported by Fundação de Amparo à Pesquisa do Estado de São Paulo (Fapesp), process 98/04178-7, 02/13450-0. To the Japanese-Brazilians,

Disclosure: no potential conflict of interest relevant to this article was reported.

\section{REFERENCES}

1. Zimmet P, Alberti KG, Shaw J. Global and societal implications of the diabetes epidemic. Nature. 2001;414(6865):782-7.

2. Martin BC, Warram JH, Krolewski AS, Bergman RN, Soeldner JS, Kahn CR. The role of glucose and insulin resistance in development of type 2 diabetes mellitus: results of a 25 -year follow-up study. Lancet. 1992;340(8825):925-9.

3. Weyer C, Borgardus C, Mott DM, Pratley RE. The natural history of insulin secretory dysfunction and insulin resistance in the pathogenesis of type 2 diabetes mellitus. J Clin Invest. 1999;104(6):787-94.

4. Laaksonen DE, Toppinen LK, Juntunen KS, Autio K, Liukkonen KH, Poutanen KS, et al. Dietary carbohydrate modification enhances insulin secretion in persons with the metabolic syndrome. Am J Clin Nutr. 2005;82(6):1218-27.

5. Juntunen KS, Laaksonen DE, Poutanen KS, Niskanen LK, Mykkänen HM. High-fiber rye bread and insulin secretion and sensitivity in health postmenopausal women. Am J Clin Nutr. 2003;77(2):385-91.

6. Gimeno SGA, Ferreira SRG, Franco LJ, Hirai AT, Matsumura L, Moisés RS. Prevalence and 7-year incidence of type II diabetes mellitus in a Japanese-Brazilian population: an alarming public health problem. Diabetologia. 2003;45(12):1635-8.

7. Freire RD, Cardoso MA, Gimeno SG, Ferreira SR; JapaneseBrazilian Diabetes Study Group. Dietary fat is associated with metabolic syndrome in Japanese Brazilians. Diabetes Care. 2005;28(7):1779-85.

8. Weng J, LiY, Xu W, Shi L, Zhang Q, HuY, et al. Effect of intensive insulin therapy on b- cell function and glycaemic control in patients with newly diagnosed type 2 diabetes: a multicentre randomized parallel-group trial. Lancet. 2008;371(9626):1753-60.

9. Chailurkit L, Chanprasertyothin S, Jongjaroenprasert W, Ongphiphadhanakul B. Differences in insulin sensitivity, pancreatic beta cell function and circulating adiponectin across glucose tolerance status in Thai obese and non-obese women. Endocrine. 2008;33(1):84-9.

10. Matthews DR, Hosker JP, Rudenski AS, Naylor BA, Treacher DF, Turner RC. Homeostasis model assessment: insulin resistance and beta-cell function from fasting plasma glucose and insulin concentration in man. Diabetologia. 1985;28(7):412-9.

11. Kahn SE. The relative contributions of insulin resistance and betacell dysfunction to the pathophysiology of type 2 diabetes. Diabetologia. 2003;46(1):3-19.

12. Abdul-Ghani MA, Tripathy D, DeFronzo RA. Contributions of -cell dysfunction and insulin resistance to the pathogenisis of impaired glucose tolerance and impaired fasting glucose. Diabetes Care. 2006;29(5):1130-9.

13. Liese AD, Schuls M, Fang F, WoleverTMS, D'Agostino RB, Sparks $\mathrm{KC}$, et al. Dietary glycemic index and glycemic load, carbohydrate and fiber intake, and measures of insulin sensitivity, secretion, and adiposity in the Insulin Resistance Atherosclerosis Study. Diabetes Care. 2005;28(12):2832-8.

14. Liese AD, Roach AK, Sparks KC, Marquart L, D'Agostino RB, Mayer-Davis EJ. Whole-grain intake and insulin sensitivity: the Insulin Resistance Atherosclerosis Study. Am J Clin Nutr. 2003;78(5):965-71.

15. World Health Organization. Steering Committee of the Western Pacific Region of the World Health Organization, the International Association for the Study of Obesity, and the International Obesity Task Force. The Asia-Pacific perspective: redefining obesity and its treatment. Geneva:WHO; 2000.

16. Cardoso MA, Kida AA, Tomita LY, Stocco PR. Reproducibility and validity of a food frequency questionnaire among women of Japanese ancestry living in Brazil. Nutr Res. 2001;21(5):725-33.

17. Foster-Powell K, Holt SHA, Brand-Miller JC. International table of glycemic index and glycemic load values: 2002. Am J Clin Nutr. 2002;76(1):5-56.

18. Alberti KGMM, Zimmet PZ. Definition, diagnosis and classification of diabetes mellitus and its complications. Part 1: diagnosis and classification of diabetes mellitus provisional report of a WHO consultation. Diabetic Med. 1999;15(7):539-53.

19. WallaceTM, Levy JC, Matthews DR. Use and abuse of HOMA modeling. Diabetes Care. 2004;27(6):1487-95.

20. Kang ES, YunYS, Park SW, Kima HJ, Ahn CW, SongYD, et al. Limitation of the validity of the homeostasis models assessment as an index of insulin resistance in Korea. Metabolism. 2005;54(2):206-11.

21. Mckeown NM, Meigs JB, Liu S, Wilson PWF, Jacques PF. Wholegrain intake is favorably associated with metabolic risk factors for type 2 diabetes and cardiovascular disease in the Framingham Offspring Study. Am J Clin Nutr. 2002;76(2):390-8.

22. WoleverTMS, Mehling C. High-carbohydrate-low-glycemic index dietary advice improves glucose disposition index in subjects with impaired glucose tolerance. Br J Nutr. 2002;87(5):477-87.

23. Jenkins DJA, Kendall CWC, Augustin LSA, Franceschi S, Hamidi $M$, Marchie $A$, et al. Glycemic index: overview of implications in health and disease. Am J Clin Nutr. 2002;76(1):266-73.

24. International Diabetes Federation (IDF). The IDF consensus worldwide definition of the metabolic syndrome. IDF, 2006. Disponível em: http://www.idf.org/webdata/docs/MetSyndrome_FINAL. pdf [Acesso em 3/1/2009].

25. Liu S, Manson JE, Buring JE, Stampfer MJ, Willett WC, Ridker PM. Relation between a diet with a high glycemic load and plasma concentrations of high-sensitivity C-reactive Protein in middle-aged women. Am J Clin Nutr. 2002;75(3):492-8.

26. Liu S, Manson JE, Stampfer MJ, Holmes MD, Hu FB, Hankinson $\mathrm{SE}$, et al. Dietary glycemic load assessed by food-frequency questionnaire in relation to plasma high-density-lipoprotein cholesterol and fasting plasma triacylglycerols in postmenopausal women. Am J Clin Nutr. 2001;73(3):560-6. 